Article

\title{
The 'Lunar Side' of the Story: Exploring the Sustainability of Curricular Internships in Higher Education
}

\author{
Betina Lopes ${ }^{1,2, *(\mathbb{D})}$, Patrícia Silva ${ }^{3,4}$, Ana I. Melo ${ }^{3,5,6}{ }^{(\mathbb{C}}$, Elisabeth Brito ${ }^{3,5}$, \\ Gonçalo Paiva Dias ${ }^{3,5}$ (D) and Marco Costa ${ }^{5,7}$ (D) \\ 1 Research Centre on Didactics and Technology in the Education of Trainers (CIDTFF), University of Aveiro, \\ 3810-193 Aveiro, Portugal \\ 2 Department of Life Sciences, University of Coimbra, 3000-370 Coimbra, Portugal \\ 3 Research Unit on Governance, Competitiveness and Public Policies (GOVCOPP), University of Aveiro, \\ 3810-193 Aveiro, Portugal; patriciasilva@ua.pt (P.S.); ana.melo@ua.pt (A.I.M.); ebrito@ua.pt (E.B.); \\ gpd@ua.pt (G.P.D.) \\ 4 Department of Social, Political and Territorial Sciences, University of Aveiro, 3810-193 Aveiro, Portugal \\ 5 School of Technology and Management (ESTGA), University of Aveiro, 3750-127 Águeda, Portugal; \\ marco@ua.pt \\ 6 Center for Research in Higher Education Policies (CIPES), 4450-227 Matosinhos, Portugal \\ 7 Center for Research \& Development in Mathematics and Applications, University of Aveiro, \\ 3810-193 Aveiro, Portugal \\ * Correspondence: blopes@ua.pt
}

Received: 29 August 2019; Accepted: 18 October 2019; Published: 23 October 2019

\begin{abstract}
Curricular internships are increasingly seen as an effective strategy capable of contributing to the objectives and targets of the sustainable development paradigm, both in its social, economic and institutional dimensions. This positive outlook is ingrained within the large bulk of existing research, which has been focused on the discussion of positive outputs, such as the enhancement of graduates' competences (employability) and their work integration (employment). An important, albeit relatively unexplored, feature of the sustainable institutional politics of curricular internship management pertains to the assessment of its associated liabilities and tensions. This article seeks to address this challenge, by analyzing two interrelated dimensions. First, it seeks to understand the internship processes ranging from the planning to the implementation stages. Second, it elicits the associated negative aspects (the 'lunar side') of internships, allowing for an assessment of the features where there is room for improvement. Empirically, this article draws on in-depth qualitative research. It presents the results of four focus groups, voicing the perceptions of top management structures and students involving first cycle degrees in the areas of Marketing, Management, and Accounting from four public Portuguese Higher Education Institutions (HEIs)-three polytechnics and one university. Findings confirm the general positive outlook of internships. Perceived negative perspectives report to both internal problems (such as the lack of institutional support and curricular design) and external problems (e.g., the shortage of suitable internship placements), constituting barriers towards sustainable institutional policies and strategies. Adaptive strategies to overcome specific difficulties are highlighted (e.g., establishment of advisory committees with local businessmen). Finally, recommendations regarding curricular internship management at HEIs are delineated (e.g., investment in monitoring and evaluation strategies of internships).
\end{abstract}

Keywords: curricular internships; higher education; graduate employability and employment; institutional management; focus group; content analysis; case study 


\section{Introduction}

There has been a major public discourse valuing internship experiences in Higher Education (HE). Such relevance is potentially due to the growing concern with youth unemployment, with current empirical research largely depicting the positive value of this particular learning strategy, either in terms of graduates' professional development or work integration.

Even though the positive impacts of internships are acknowledged, there is a risk of 'telling only half the story' by focusing just on the 'bright' (solar) side of internships and therefore possibly contributing to less successful institutional strategies concerning internships. Sustainable institutional politics can only emerge if negative aspects, as well as its associated liabilities and tensions, are also considered. In fact, the 'solar side' of the existing research and overall political and media debates tends to overshadow the far side of internships. Hence, the 'lunar side' (less positive features) needs to be outshined in order to build sustainable strategies for graduate students and HEIs.

The Sustainable Development Agenda 2030 (SDA) of the United Nations [1], as a global development agenda [2], increases the responsibilities of HEIs and curricular internships' management, particularly considering Goal 4 "Quality Education", Goal 8 "Decent Work and Economic Growth" and Goal 16 "Peace, Justice and Strong Institutions". For the purpose of this paper, a conceptual framework based on the SDA and on Spangenberg's prism of sustainability' [3] was developed-Figure 1.

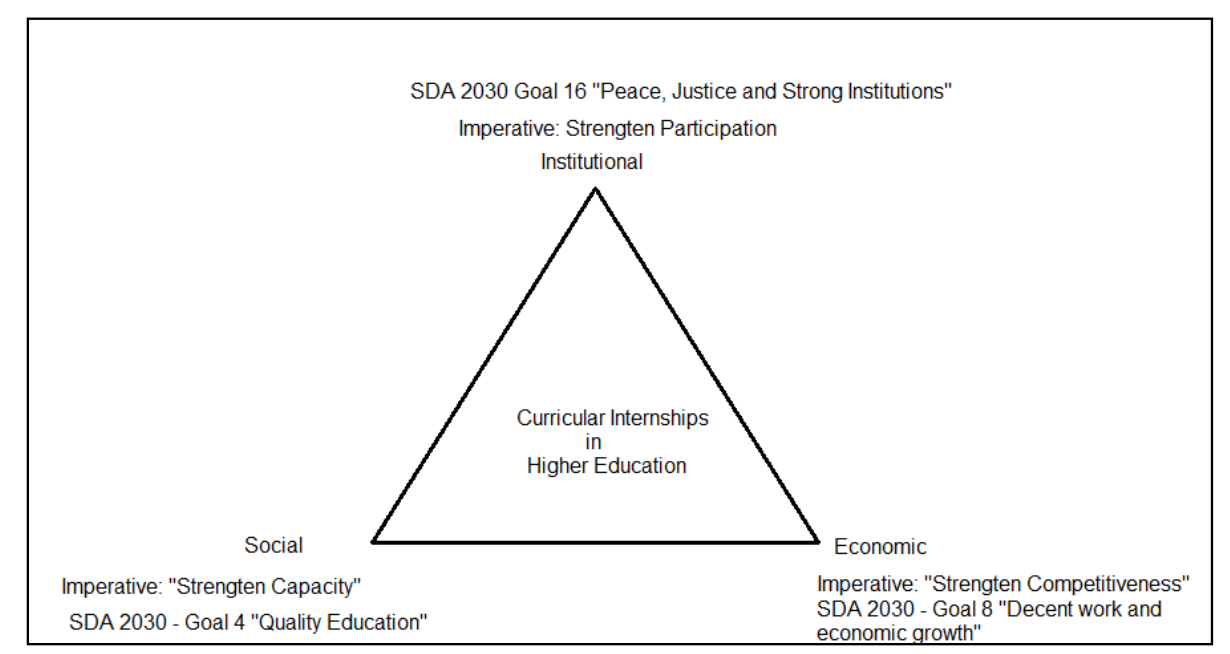

Figure 1. Sustainability and Curricular Internships at Higher Education—a framework.

According to this framework, the sustainability of curricular internships' management in HE entails three interrelated dimensions: the social, the economic, and the institutional. The social dimension relates to the 'human capital' (such as the intra-personal qualities of human beings, namely skills, dedication, and experiences) and is focused on capacity strengthening. This dimension is conceptually linked to target 4.4. of the SDA (https://www.un.org/sustainabledevelopment/education/). As this target highlights, it is expected that by 2030 , there will be a substantial "increase [in] the number of youth and adults who have relevant skills, including technical and vocational skills, for employment, decent jobs, and entrepreneurship." The economic dimension is related to the 'man made capital', including not only the formal economy but also all kinds of informal activities that provide services to individuals and groups focused on competitiveness. This dimension can be conceptually linked to targets 8.5 and 8.6 (https://www.un.org/sustainabledevelopment/economic-growth/). These targets expect to "achieve full and productive employment and decent work ( ... ), including for young people, ( ... ) and equal pay for work of equal value" and to "substantially reduce the proportion of youth not in employment, education or training." The institutional dimension is the result of interpersonal processes, such as communication and co-operation at several levels and is sustained on participatory processes. This dimension can be conceptually linked to SDA target 
16.6(https://www.un.org/sustainabledevelopment/peace-justice/), as it seeks to "develop effective, accountable and transparent institutions at all levels", while target 16.7 aims at ensuring "responsive, inclusive, participatory and representative decision-making $(\ldots)$ ".

This article seeks to contribute to sustainable approaches regarding curricular internships in HE First Cycle Degrees (FCD). It is structured in the following way: first, it begins with the literature review, which discusses the perceived and measured values of curricular internships in HE (the 'solar side' of internships/internships as an 'asset'), looking at several research findings and corresponding interpretive theoretical frameworks in order to identify main research gaps. Second, the methodological dimension of the study is presented by describing the research background and rational, and the qualitative methods used. Third, results are presented in four subsections, one for each of the four Portuguese cases selected for the study. Fourth, in the discussion section, global recommendations are made, based on the triangulation of the cases and in articulation with the 'sustainability framework' regarding HEIs and curricular internships. Finally, the major conclusions of the study are highlighted, the limitations of the study are presented and future avenues of research discussed.

\subsection{Literature Review: The Solar Side of Internships}

Before addressing the practical dilemmas of internships in terms of policy and institutional practices, it must be discussed conceptually. One can find considerable scholarly debate regarding what constitutes internships. Indeed, its very categorization is contested, let alone its definition. Moreover, the growing usage of the term internship in public discourse has done little to simplify its definition.

In fact, there is no single, unique expression to label this type of 'learning while working' experience [4-6]. The most common designations are vocational training $[7,8]$, practicum or practical training [9], work placement [10,11], (early) workplace learning [10], as well as apprenticeship, traineeship or internship [12-14]. Within this study the term (curricular) internship was adopted, due to the fact that it is the closest word to the common term used in the Portuguese Higher Education scenario-"estágios curriculares" [15-17]-the national context of this study.

However, in terms of literature review, we have looked at studies that reported findings related to pedagogical experiences in FCD, which include the possibility of students to contact with real working experiences outside the academia [18], being guided by, at least, two more experienced supervisors, one belonging to a HEI and the other to an employing institution $[15,16]$. These work experiences are broadly known as "Work Integrated Learning", in short WIL strategies [19-21].

The value of internship experiences has been widely stated and defended by a vast body of literature based on empirical evidence from all over the world, and which can be roughly grouped into two distinct, but complementary focuses, namely "focus on learning processes" (perspective 1) and "focus on the knowledge economy" (perspective 2).

\subsubsection{Internships as a Learning Process}

This perspective is represented by research mainly focused on investigating how and why internship experiences enhance the possibility of students to acquire and to develop work related competences. Reported findings are mainly sustained by analytical frameworks associated with (socio constructivist) learning models. It is widely stated that students learn and develop within internship experiences [11,22-24]. The list of personal and professional gains during an internship is vast, even though sometimes diffuse and overlapping $[5,13,25]$. Three major types of advantages contributing to an increased 'work-readiness' and higher 'employability' can be elicited:

- increased 'understanding of subject matter': 'internships allow students to apply the contents ('theoretical knowledge') they explored during classes in real working contexts, thus promoting the clarification of their understanding and therefore enhancing the mastery of the subject matter of the degree [13,26-28],

- promotion of 'skillful practices', also designated as 'procedural knowledge' or 'behavioral competence': internships allow students to develop a range of personal, performative and 
organizational skills that go beyond the more 'traditional' academic, theoretical knowledge and skills. For example, according to Alves [29], graduates are notoriously ignorant of the rules, behavior, communication, and relationships, culture and values prevailing in working environments. The authors also defend that undertaking formal work training helps to make graduates more competent and capable of doing their job after graduating, being the development of metacognitive processes crucial (self-awareness of what one knows and can do, and of how he/she can learn more in the most efficient way),

- enhanced 'efficacy beliefs': research claims that internship experiences may reduce the 'emotional shock' reported by many students when facing the job market for the first time since they have the opportunity to establish early contact with 'employers' and 'co-workers' [12,17]. Internships represent an opportunity for students to get the first sense of a job without losing the 'institutionalized' support of their academic supervisors [17], thus contributing to higher self-esteem of graduates and, therefore, to an increased willingness to adopt a pro-active posture when seeking a job [12,24].

\subsubsection{Internships within the Knowledge Economy}

The theoretical foundations of this second perspective are mainly anchored on economics and management theories. The focus is on researching if internships enhance the possibility of graduates entering the job market and the extent to which they increase the employment rate of graduates and other characteristics of employment (e.g., salaries and employees' satisfaction).

A growing perception of internships as positional goods for job seeking [30] and job accessing [14,15,30,31] is manifest due to growing youth unemployment problems [24]. As a response, a growing number of HEIs have been using internships as a mean of communicating to students and the wider community their commitment to graduate employment [24,32]. In fact, several studies report that internship experiences tend to constitute a recruitment criterion [12,15,33,34], enhancing the possibility of acquiring references, which may be crucial for future career moves. Each internship placement allows students to integrate a 'professional network', giving him/her the opportunity to 'socialize' with several professionals that may constitute key contacts (in the best scenario, a future 'employer') in the effort of getting a first job [34-36]. According to a large-scale study conducted in Portugal, mandatory internships and the inclusion of multiple, shorter internships throughout FCD tend to be negatively associated with the unemployment levels of graduates [15,16].

As such, the 'solar side' of internships emerges as a more prominent strand in the literature. To some extent, HEIs have invested considerable resources to develop and improve graduate employment, particularly considering that work-related experiences are generally regarded as a win-win-win opportunities for students, employers, and HEIs (see, inter alia, [35]. Despite the impressive research on curricular internships and the public discourse encouraging the use of such strategies, many questions remain unanswered. First, evidence on the practical benefits of internships tends to be based on students' [36] or employers' (see, for example, [30,37-41] expectations and perceptions. In fact, there seems to be an absence of empirical research cross-checking the perspectives of the main stakeholders involved in the development and implementation of internships (degree coordinators, supervisors), whose perceptions have been 'terra incognita' in this domain.

Moreover, the empirical assessment of stakeholders' perceptions on internships has also been limited. In fact, the data collection instruments tend to be based on interviews, known to be more prone to eliciting the brighter (solar) side of internships. In contrast, focus groups and group interactions tend to lead participants to identify and clarify their perspectives, by encouraging them to share experiences and opinions that might not surface during individual interviews, particularly considering the potential unstructured nature of focus groups. Additionally, this interaction can potentially highlight the liabilities and tensions associated with the implementation of internships, allowing for an assessment of the features where there is significant room for improvement. 
Given this identified gap in the literature, the aim of this study is to elicit liabilities and tensions related to internship processes from the planning to the implementation stages of FCD from 4 public Portuguese HEI.

\section{Methods}

The study reported in this paper was conducted within a broader sequential mixed method study [42] focused on linking data from two separate, but interlinked stages. The first stage (quantitative approach) included the inventory of nearly 200 FCD and sought to understand the impact of internships on graduates' employment (access to work) while controlling for other institutional and contextual variables [15]. This stage of research informed the second stage, namely regarding the selection of cases, as well as the within-case analysis strategy. It preceded the in-depth study of some cases that digged deeper into the processes of organizing and managing internships, including its associated liabilities and tensions.

In order to ensure the comparability of the data to be collected from each case, it was decided to confine the FCD to interrelated areas. The areas chosen were Marketing and Management and Accounting since these FCD revealed to be the ones where internships are more common $[15,16]$. Four HEIs were chosen based on the effort in maintaining some diversity regarding:

(i) the type of institution, namely university vs. polytechnic. While polytechnic institutions tend to provide a more practical and professionally oriented training-hence, theoretically, more prone to the establishment of internships, the university system tends to be associated with a stronger theoretical basis and tends to be more research oriented. This once sharp distinction seems, however, to have become increasingly blurred over time.

(ii) the geographical localization (costal vs. inland), since Portugal's inland is characterized by depopulation, stagnation, and delay, being the levels of social and economic maladjustment difficult to reverse, thus contributing to lower levels of development $[43,44]$.

(iii) nature (mandatory vs. facultative) of internships, since previous research $[15,16]$ indicated that compulsory internships significantly impact on graduate employment.

Overall, this sequential combination of a mixed methods approach derived from the abundant research on the potential variables impacting on graduates' employment, though the independent impact of internships had been scarcely demonstrated.

This article presents a within-case analysis, reporting the use of internships in seven FCD offered by four Portuguese HEIs. A focus group was conducted in each institution in 2014, in a context when Portugal was embarking on a narrative of austerity, implementing wide-ranging fiscal consolidation measures to reduce public spending. The economic downturn amplified the demand for local public services in the face of high unemployment, a pressure to which HEIs were surely not immune to [14-16].

The first case (CASE A) corresponds to a polytechnic school and involved stakeholders from the 'Marketing Degree'. The second case (CASE B), corresponds to a public university and involved stakeholders from two FCD: 'Management' and 'Accounting'. The third and fourth cases (CASE $\mathrm{C}$ and CASE D), correspond to two polytechnic schools. Concerning CASE C, three degrees were considered: 'Management', 'Marketing', and 'Tourism'. To note, that the inclusion of the Tourism degree resulted from the suggestion of the participants. Once explained the research main goals, the Head of Department, asked if it would be possible to include supervisors and students from Tourism. He argued it would be an excellent opportunity for collaborative reflection, and institutional innovation. Considering that the researchers' aim is also to inform institutional practices ('applied research') it was decided to include these participants also.) CASE D involved the 'Management Degree'. Table 1 presents a brief outline of the institutional policy regarding internships in each of the involved institutions. As depicted, the diversity of cases, along with the wide spectrum of internship strategies used by each institution, enables a deep understanding of the organization and functioning of internships in Portuguese HEIs, thus enhancing the accuracy of the findings. The geographical localization of each HEI is also identified. 
Table 1. Institutional Internship Policies of Four Portuguese Public HEIs.

\begin{tabular}{|c|c|c|c|c|}
\hline & Case A Coastland & Case B Inland & Case C Inland & Case D Coastland \\
\hline Involved Degrees & Marketing & Management \& Accounting & Management, Marketing \& Tourism & Management \\
\hline Curricular Background & Degree always offered internships. & $\begin{array}{l}\text { Internships introduced within the last } \\
\text { curricular reform (2008) as a response to } \\
\text { external pressures. }\end{array}$ & $\begin{array}{l}\text { Management and Marketing always had } \\
\text { internships. Tourism included an internship as } \\
\text { a response to the success of extracurricular } \\
\text { internships and students' pressure. }\end{array}$ & The Degree always offered internships. \\
\hline $\begin{array}{c}\text { Formal } \\
\text { coordination/management } \\
\text { structure }\end{array}$ & $\begin{array}{l}\text { Inexistent (Supervisors in collaboration } \\
\text { with Degree Director, being mainly } \\
\text { sustained on peer support). }\end{array}$ & $\begin{array}{l}\text { Inexistent (Supervisors in collaboration } \\
\text { with Degree Director). The employment } \\
\text { office gives some support (paper work). }\end{array}$ & $\begin{array}{l}\text { Internship coordinator (who works closely } \\
\text { with the internal supervisors of each degree) }\end{array}$ & $\begin{array}{l}\text { Internship Commission (responsible for } \\
\text { the allocation of interns outside the } \\
\text { campus and the nomination of the } \\
\text { academic supervisor) }\end{array}$ \\
\hline Internships Nature $^{1}$ & Facultative & Facultative & Facultative with numerus clausus & Compulsory \\
\hline Internships Structure $^{2}$ & Single at the end of the degree & Single at the end of the degree & Single at the end of the degree & Single at the end of the degree \\
\hline Internship Duration & $324 \mathrm{~h}$ ( 1 semester $)$ & $400 \mathrm{~h}$ (1 semester) & $\begin{array}{l}\text { Management and Tourism 400h, Marketing: } \\
\qquad 280 \text { (1 semester) }\end{array}$ & 10 weeks $/ 3$ months \\
\hline Internship Regime ${ }^{3}$ & $\begin{array}{l}\text { Full time, but with curricular units at the } \\
\text { same time }\end{array}$ & Part time & $\begin{array}{l}\text { Full time (Management \& Tourism) Part time } \\
\text { (Marketing) }\end{array}$ & Full time \\
\hline Students' internship allocation & $\begin{array}{l}\text { Internships are proposed by the } \\
\text { university. In cases with huge demand, } \\
\text { serialization is made by companies. In } \\
\text { some rare cases, students' proposals are } \\
\text { accepted after close analysis by the } \\
\text { Degree Director. }\end{array}$ & $\begin{array}{l}\text { Decided by the supervisors only (no } \\
\text { interference of students, nor companies). } \\
\text { Students apply and are allocated by the } \\
\text { Degree Director to an institution } \\
\text { according to their profile (basic skills: } \\
\text { language and IT skills are assessed). }\end{array}$ & $\begin{array}{l}\text { Numerus clausus. The academia has a list of } \\
\text { collaborators. Students are serialized by the } \\
\text { internship coordinator according to their } \\
\text { profile (competences and interests). Students } \\
\text { can also propose an internship. The internship } \\
\text { coordinator evaluates the proposals. The } \\
\text { internship can even be outside Portugal. }\end{array}$ & $\begin{array}{l}\text { Students propose their internship in an } \\
\text { internship plan (analyzed and approved } \\
\text { by the Internship Commission). }\end{array}$ \\
\hline
\end{tabular}


As stated above, data gathering of the qualitative study included focus-group with different stakeholders in each institution (deans, departmental directors, degree directors, and former students) to access a truly pluralist perspective. It was assumed that the use of mixed groups enhanced the emergence of different and even opposite perspectives while increasing the opportunity of a broader understanding of institutional internship policies. This strategy allowed for circumventing the traditional single interview format, with classical questions that could elicit politically correct answers or rehearsed speeches [23]. Extensive literature review on curricular internships did not reveal any study where stakeholders from the same institution, and therefore sharing the same or similar internship experiences, talked to each other about internships. In fact, the majority of studies tend to be single voiced $[17,21,34]$. Furthermore, the opportunity to give voice to all participants involved converges to institutional sustainability (Figure 1), enhancing the aspects of equity and justice [3]. Table 2 resumes the four focus-groups that were conducted, with a total of 21 participants from seven degrees, as aforementioned.

Table 2. Focus groups in the four cases.

\begin{tabular}{cll}
\hline Focus-Group & \multicolumn{1}{c}{ Participants } & \multicolumn{1}{c}{ Institutional Context } \\
\hline A & $\begin{array}{l}\text { 1 Director of the degree with previous supervisor } \\
\text { experience 2 supervisors 2 former students }\end{array}$ & $\begin{array}{l}\text { Case A Degree: Marketing One single } \\
\text { internship at the end of the degree }\end{array}$ \\
\hline B & $\begin{array}{l}\text { Dean 1 Director of 'Accounting' with previous } \\
\text { supervisor experience No students }\end{array}$ & $\begin{array}{l}\text { Case B Degrees: Accounting and Management } \\
\text { One single internship at the end of the degree }\end{array}$ \\
\hline C & $\begin{array}{l}\text { 1 Head of the Department 3 Degree Directors (one } \\
\text { for each degree, with previous supervisor } \\
\text { experience) 1 supervisor involved in 2 degrees 4 } \\
\text { former students }\end{array}$ & $\begin{array}{l}\text { Onegrees: Management, Marketing and Tourism } \\
\text { Ongle internship at the end of the degree }\end{array}$ \\
\hline D & $\begin{array}{l}\text { 1 Head of the Department 1 Degree Director with } \\
\text { previous supervisor experience 1 former student }\end{array}$ & $\begin{array}{l}\text { Degree: Management One single internship at } \\
\text { the end of the degree }\end{array}$ \\
\hline
\end{tabular}

The focus groups were structured in three main moments:

(i) First, participants were asked to describe the institutional background of the curricular internships. Here the starting questions were: since when does the degree offers internships and why? How are internships managed? Who is responsible for assuring internship vacancies and communicate with possible institutions? How are internships organized considering the curricular plan of the degree? To what extent are the employers involved in degree design? Naturally, during this initial part, academic participants were the main actors, even though it was emphasized that students could also intervene, commenting on academics' opinions.

(ii) During the second part, participants were asked to focus and describe specific internship experiences, including their contexts, as well as positive and negatives aspects, relating it to their roles, responsibilities around those internships, as well as other responsibilities (in the case of the academics) or life-projects (in the case of former students). The following questions were asked: What was your last internship experience (Where? How long? With who? What was your supervision/learning experience like?) How were students assessed? Were there any conflicts/tensions? If yes, how were they overcome? What would you do differently and why?

(iii) Finally, outputs of the first stage of the sequential mixed method study were presented $[15,16]$, namely regarding the impact of the internship experience on the employment of graduates on the long run (12 months after graduation) This strategy aimed to reinforce the validity $[45,46]$ of the study. Participants were asked to comment on those previous findings, relating them with their personal experience. This final part was closely inspired on the 'task-based interview' [47], where participants are asked to comment out loud their personal thoughts while performing specific tasks, in order to open the opportunity to access "true experiences and not only ways of talking". This enables different stakeholders that had a close internship experience (since they are from the same institution) to exchange and confront opinions on the same phenomenon, aiming to put each 
participant within an 'equal' position. This does not only reduce the risk of transference/contra transference between researchers and focus group participants $[45,46]$ but also reflects an important aspect of institutional sustainability: involving different participants in the process.

A content analysis of the verbatim transcripts of each focus group was conducted by two researchers of the team, being validated by the other four. The research results focused on the positive aspects ('the solar side') of internships were published [44], being in alignment with the perspectives 1 and 2 presented in the literature review section.

The growing practice of integrating internship experiences by HEIs in the recent years in Portugal [4], as well as at a global level [33] and, therefore, the growing need to inform institutional managers on how to implement more sustainable strategies of internships justified the re-analysis of each focus group, focusing on identifying the 'lunar side' of internships. Therefore, a second content analysis of the four focus group sessions was conducted with the support of the software WebQDA ${ }^{\circledR}$. The definition of the categories was inspired by a common strategic planning technique known as SWOT analysis [48]. SWOT analysis enables the identification of positive and negative aspects, both of internal and external nature, that influence the quality and success of the object under analysis and has been used as an instrument for supporting management decisions [48], since it facilitates the definition and prioritization of actions (What should be favored? And what should be avoided?). In this specific second cycle of analysis only external and internal negative aspects were extracted, since positive aspects, as previously mentioned, were already elicited for each institution and can be consulted at [4]. The coding process implied a recursive/iterative process of combining the definition of categories and subcategories, as well as the extraction of evidence from each transcript, with the global review of previous analyzed verbatim transcripts. This constant comparison between rough and treated data aimed at enhancing the trustworthiness and resonance of the findings $[45,46]$.

\section{Results}

Results are structured as four research cases, which may be used as primers for institutional reflection. Within each HEI, the internal challenges and external negative aspects mentioned by the different stakeholders are elicited. For the description of each case, the following strategy was adopted: each case starts with a global comparison of the number of references to internal vs. external problems (in order to check if tensions are more associated with internal aspects (fragilities) or external aspects (threats). The categories (subcategories) most referred to are highlighted, passing to the categories (subcategories) less referred to, assuming that the frequency of references reflects the importance of the aspect under discussion for the participants (problems and tensions regarding internship experiences) In some cases participants discuss how some of the problems mentioned were overcame.

\subsection{Case A: Internships Guarantee Work(Load)!/“Os Estágios São Trabalho!"}

Within this focus group, in which the Degree Director was clearly the leader, with large previous experience as an internship supervisor, internal institutional problems were more referred to (10 references) than external challenges, with 5 references (Table 3).

Concerning internal challenges, the lack of institutional structures (such as an Internship Commission) that support the several (administrative/bureaucratic) tasks associated to the internship ministration, such as the searching for (good/adequate) internship placements, formal establishment of protocols, and on site visiting during the internship was mentioned five times along the interview (one time by the Director of the Degree and four times by supervisors). Interestingly, and according to the Director of the Degree, existent services sometimes even introduce more difficulties and more workload due to the lack of acknowledgement of the dynamics associated to hosting institutions, exemplifying with a protocol signature, where the university demanded a signature by the manager of a multinational company: 
"(... ) formal requirements from the part of the university are often not compatible with what companies are willing to formalize (... ) An Italian administrator signing an internship protocol?! ... Here we are in the realm of fantasy!"

Table 3. The 'lunar side' of internships from Case A-main categories and illustrative examples.

\begin{tabular}{|c|c|c|}
\hline Category & Relation to the Institution & Example of Testimony \\
\hline $\begin{array}{l}\text { Lack of (adequate) institutional } \\
\text { support structure ( } 5 \text { references) }\end{array}$ & Internal & $\begin{array}{l}\text { “( ... ) The professionalization of this type of instrument } \\
\text { [internships) is missing. ( ... ) There should be a structure } \\
\text { adequately designed to deal with this quickly }(. . .) \text { also to } \\
\text { enhance the possibility of some processes that are quite } \\
\text { important getting out of anonymity ... for example, the press } \\
\text { releases ... a formal internship signature." (Supervisor } 2) \text {. }\end{array}$ \\
\hline Curricular design (4 references) & Internal & $\begin{array}{l}\text { "Each internship has } 324 \mathrm{~h} \text {, all in a working context }(\ldots) \\
\text { what is not enough, by the way. Students complain a lot, and } \\
\text { then they have other courses simultaneously, which } \\
\text { complicates the process }(\ldots) \text { " (Supervisor } 1)\end{array}$ \\
\hline University Teachers (1 reference) & Internal & $\begin{array}{l}\text { "This is related to the way internships work. The workload is } \\
\text { considerable [laughs] Some people think they don't ... but } \\
\text { they do work a lot. So, a lot of vicissitudes emerge here. You } \\
\text { have to deal with grumpy business men ..." (Degree Diretor) }\end{array}$ \\
\hline $\begin{array}{l}\text { Lack of adequate internship } \\
\text { placements ( } 5 \text { references) }\end{array}$ & External & $\begin{array}{l}\text { "( ... ) Sometimes some less positive situations happen } \\
\text { [referring to inadequate internship placements]. We always } \\
\text { have to safeguard }(\ldots) \text { the student }(\ldots) \text { " (Supervisor } 1)\end{array}$ \\
\hline
\end{tabular}

Even though the Director of the Degree, as well as the two supervisors, were very enthusiastic considering the suggestion of implementing more than one internship along the study program, recognizing its advantage to students' development and eventually work integration, all three agreed that this would require a deeper institutional support, and, again, much more workload for those who are already cluttered by internship tasks:

"I am an apologist of thin sandwich courses [several internships along the degree] ... but considering the implementation point of view, this implies some complexity, because (... ) all of this would have to be more administratively supported. If even now, with only one internship at the end of the study program, it has been highly complicated, it would be even much more complex with more than one( ... ). We would need a very different support structure!"

However, acknowledging the benefits of internships on students', one supervisor highlighted that they introduced a complementary strategy in order to anticipate students' work contact, within the context of a specific compulsory curricular unit. The strategy, called "the institution's project", implied the invitation of specific institutions to present a particular (real) problem to the class, challenging students to think about a possible solution. This strategy allowed " (... ) students to get into contact with future employers and show off their potential $(\ldots)^{\prime \prime}$, without implying much more resources.

The second most referred to problem, with 4 references ( 1 time by the Director of the Degree, 2 times by one supervisor and 1 time by one student) was the fact that often the learning path is not completely closed, meaning that not all learning objectives are accomplished since internships are too short. This challenge may signal the fragilities of the study program's curricular design. As the Director of the Degree asserted, "Internships should be longer, ideally the double of time, this would be perfect for students to better integrate in the company and develop specific tasks and ... actually finish (!) those tasks".

One of the two students complemented on the Director's testimony, stating:

"I am currently attending classes AND the internship, and this is very complicate to manage. I think it would be appropriate to switch some disciplines or even suppress them and allocate more hours to the internship (...) since internship hours are very scarce (...) when we finally get used to the company, we leave!" 
Again, institutional adaptive practices to minimize these specific problems were brought up, namely the change of the week schedule of some of the other curricular units (more intense in specific months) in order to allow these curricular units to be completed earlier, relieving students' workload when they start the internship. Based on the group discussion, the Director of the Degree committed himself to reanalyse the schedules of the curricular unit and introduce the possibility of students to attend, at least, three fulltime days per week at their internship placement.

As a third internal challenge, the particularities of the internship supervisors' profile were brought up. According to the Director, not every teacher is adequate for the required responsibilities, stating that many academics feel uncomfortable in leaving the academy and contacting with the business world.

Finally, concerning external challenges, the effort of assuring adequate internship placements, where students actually learn something (and are not merely used as free working force) was mentioned five times (three times by the Director and two times by the supervisors). As reported by a supervisor, "I know I should not say this, but the university also rejects some companies. This is when we get negative feedback from students ... when we realise that the company does not offer conditions for an adequate learning experience in the following year this company does not receive any students" (Supervisor 1).

The Director validated this assertion by specifying that internships were exceptionally interrupted in the past: "There is an internship plan with learning objectives that have to be fulfilled ( ... ). The student was left alone. ( ... ) When this happens, the situation has to be corrected!"

\subsection{Case B: "Good Internship Placements Are a Scarce Resource"}

Within this focus group, external problems to the institution dominated the discussion (with 20 references). Internal problems where mentioned 13 times (Table 4). In this focus group, the discussion was mainly led by the Dean.

Table 4. The 'lunar side' of internships from Case B—categories and illustrative examples.

\begin{tabular}{|c|c|c|}
\hline Category & Relation to the Institution & Example of Testimony \\
\hline \multirow[t]{2}{*}{$\begin{array}{l}\text { Lack of (adequate) institutional } \\
\text { support ( } 9 \text { references) }\end{array}$} & \multirow[t]{2}{*}{ Internal } & $\begin{array}{l}\text { "... concerning formal structures (e.g., Internship Commission) } \\
\text { "there is no mediating structure between the university and } \\
\text { the company. There is no bridge to the working sector ... This } \\
\text { is the real scenario. It is always the same individuals that work } \\
\text { and invest their time.... at the bottom, the problem is the lack } \\
\text { of a supporting structure "(Degree Director). }\end{array}$ \\
\hline & & $\begin{array}{l}\text {... concerning monitoring and evaluation strategies "I } \\
\text { recognize that we do not have a consolidated system of } \\
\text { collecting feedback after internships. Maybe we should have } \\
\text { one ... What happens is that sometimes we get informal } \\
\text { feedback from our colleagues." (Dean) }\end{array}$ \\
\hline Curricular design (4 references) & Internal & $\begin{array}{l}\text { "At the same time of internships, they [students] have two } \\
\text { curricular units they have to attend to at the university and } \\
\text { this conditions the overall logistics" (Dean). }\end{array}$ \\
\hline $\begin{array}{l}\text { Lack of adequate internship } \\
\text { placements (16 references) }\end{array}$ & External & $\begin{array}{l}\text { "So, we have more students than internship placements. Our } \\
\text { internship does not have a compulsory nature because this } \\
\text { would imply guaranteeing sufficient companies ... imagine } \\
\text { we have } 60 \text { final students, this would imply arranging } 60 \\
\text { internship placements. Impossible! (laughs)" (Dean) }\end{array}$ \\
\hline $\begin{array}{l}\text { 'Manipulation' of internship } \\
\text { allocation (4 references) }\end{array}$ & External & $\begin{array}{l}\text { "We try that the companies do not interfere in the students' } \\
\text { selection, because this only complicates the entire situation. } \\
\text { We try to let them trust us. We ask them to define the profile of } \\
\text { the students they need and we make the selection." (Dean) }\end{array}$ \\
\hline
\end{tabular}

As depicted in Case A, many of the reported issues are related to internal features, with 5 references by the Director of the Degree. The lack of adequate institutional support seems to be particularly prominent:

We have the secretariat that [gives some support] by receiving documents from students and files them ... We complain a lot. When we want a timely response ... they [technical staff] give us [only vague] 
suggestions: oh ... there is this company and so on... [And I reply]. Yeah, ok. But could you handle the process? Can you arrange an internship there? [and then I get the answer] we're here to serve the whole university! And not just ONE department!

In close articulation with the lack of (more), institutional support emerged the inexistence of a monitoring and evaluation strategy regarding internships, as the Dean assumed:

“( ... ) We end up losing the chance to talk to them [interns and entrepreneurs] after the evaluation.

This is the flaw I recognize. Therefore, we lack the genuine feedback from students [ ... ] We only have [indirect] feedback by [reading] internship reports."

On a similar vein, the Degree Director reinforced that they had no concrete evidence of student employment rates that could sustain their initial perception of a positive impact on students' work integration. Both recognised that informal feedback from students along with the process is very limited since it may be conditioned. Students' formal feedback-in the form of the required report submitted for evaluation-may be positively biased, as students avoid presenting a negative outlook of the internship placement due to the fear of retaliation from their supervisors.

As a third internal problem, features associated with the curricular design were referred to four times ( 2 by the Director of Institution and 2 by the Degree Director). As in the previous HEI, students attend other curricular units while also attending their internship, so the academic workload is considerable (at least twice a week). This undermines the students' internship experiences. On the one hand, students tend to avoid internship placements in companies geographically away from the university. This generates a vicious circle, as internship agreements tend to be limited to a "narrower circle", potentially undermining the employment outcomes of internships, as these companies can hardly absorb all interns. On the other hand, this internal feature enhances the external challenges associated with internships offering: the lack of adequate internship placements, which was mentioned 16 times along the focus group and was used as the main argument for internships not being compulsory. If internships were compulsory this would imply the responsibility of assuring them to all students and this would constitute a managerial problem. In fact, this particular university is located in the interior part of the country, which has severe problems of desertification [42,43] and, therefore, on the establishment of human resources for local companies:

"We are very anxious about companies with no structure, no graduates, no office staff. [In this region] there are companies where accounting is subcontracted, there are companies that do not do marketing. There are companies in which human resources are all outsourced. There are companies that are reduced to an operational part. ( ... ) we do not seek these companies. And even in large companies, we have bad examples (... ) We want to have some control over the quality of what is being done during internships" (Dean)

The lack of adequate companies (for internships) and the lack of human resources (for companies) results in a scenario of internship placement scarcity, which significantly enhances the competition around internship placements and, therefore, the attempt to 'manipulate' the system, such as trying to integrate students in family businesses-which also reinforces the narrowing of companies willing to accept interns. This issue emerged four times throughout the session.

As a response to the major challenges of this institution, namely ensuring adequate internship placements for their students, the institution has been actively adopting complementary strategies, such as:

(i) advertising the supply side of interns in local newspapers, in order to increase internship placements. There were entities that reacted positively to this strategy,

(ii) strengthening the existing partnerships with exemplary companies, through the establishment of an advisory comittee with local businessmen.

(iii) refusing "Erasmus Internships" (students from abroad), as an attempt to 'protect' the existent good internship placements for their own students. 
While the first two strategies may be signaled as good practices, the third raises issues regarding equal access to the internship placement, as well as the possibility to create intercultural work experiences.

\subsection{Case C: "It Is (Im)Possible to Please Greeks and Trojans"}

While in previous cases internal problems (Case A) or external problems prevailed (Case B), within this focus group, a more balanced scenario emerged. Internal problems were referred to 7 times and external challenges 8 times (cf. Table 5).

Regarding internal challenges, curricular design (with three mentions) was the most referred to category. The Head of the Department as well as two Degree Coordinators (Management and Tourism), reported that internships are time-consuming learning experiences and, therefore, it is very difficult for students to articulate them with other curricular units. As a response to this, and acknowledging the learning value of internships, the Department revised all study programs in order to reduce the working hours over the last semester. To this end, ECTS for other curricular units were reduced and transferred to the internship. Furthermore, in the Management Degree, the option of a post-working hour schedule was created for students who had one or more curricular units of previous years to finish, providing students with the opportunity of attending the internship.

Other internal problems mentioned were:

(i) the lack of institutional support (with 2 mentions, 1 by the Head of the Department, and 1 by a supervisor) including in financial terms, such as the lack of travel grants allowing supervisors to make on-site visits:

"We work a lot by phone. We are currently in expenditure restraints (... ). This year we had more than 20 students ... from north to south. This complicates [supervision] a lot. So (... ) we work a lot using the phone, to maintain contact and get some feedback ... to know how things are going."

(Supervisor)

(ii) the need for ensuring working hours in the expertise field of the teachers (with 2 references). One supervisor and the Management Degree Director recalled that in 2009 study programs were reviewed in the entire university due to the Bologna reform. At the time, the University decided not to introduce internships in order to avoid supressing some curricular units which were taught by some colleagues. The decision of integrating internships happened later, as a response to the national financial crisis and as an attempt to reduce their graduates' unemployment rate. At the same time, one academic mentioned that the introduction of an internship in the study program was used as an institutional marketing strategy to atract more students. As the Degree Director of Tourism stated: “ ( . . ) as a parent I would also privilege a degree that would offer an internship $(\ldots)^{\prime \prime}$.

Coming to external challenges, the conversation was focused on the fact that the academia and the industrial private companies are two worlds apart, both in terms of functioning, demand, goals, and rationales. Despite these differences, academics recognised that articulation is required, but not always easy. Data analysis revealed four different aspects where universities and the labour market have divergent, or at least, not entirely convergent, approaches:

(i) students' evaluation - the tendency of the external supervisor to give very high grades was reported by two Degree Directors (Tourism and Marketing). The Management Degree Director provided a contrasting example, where the external supervisor penalized the students because of a personal issue, which had nothing to do with the quality of the work developed. All three Directors mentioned the need to integrate a "musculated democracy" (an expression used by the Management Degree Director), meaning that their evaluation sheme is based on the balance of all 
the information they have formally and informally gathered regarding the internship process and the students' performance. As a result of a reflexive process they sometimes decide to push up, or down, the final internship classification specified by the external supervisor.

(ii) information management- the close monitoring of the students' internship reports considering its content was mentioned twice, in order to 'protect' the institutions and nurture future relationships. As an example, the supervior mentioned that once she read a report were a student had claimed that the "[name of the employer] had no leadership skills", stating "you mean ... you cannot say this ... there are statements that simply have to be avoided".

(iii) students' selection: the Head of the Department exemplified some institutions which demand students to perform psychometric tests, being some students rejected. This situation grounds some constraints ("What are we going to do with the students that are rejected?"). The Management Degree Director challenged this positioning, stating that he believes that companies' demands to intefere in the selection process are a very positive sign. Accordingly, it is benefitial for students, since by ensuring an adequate matching between the work profile and the student, an adequate learning experience is guaranteed:

"I think it is a good sign. I prefer that the company says to me: 'we made a test and we consider that this student is not adequate' than to say 'we take all interns' and then give them tasks such as copying and cleaning files (... )."

(iv) working agenda/shedules: the fact institutions had very specific time agendas was mentioned by all three working areas (Management, Marketing, and Tourism). For example, the Degree Director of Tourism stated that the hosting companies requested that internships would be during the summer time since outside the high season there was not enough work and it would not depict a 'real working context'. As a response, Tourism internships started to be sheduled one month later. However, as it was recognized by the Degree Director, and highlighted by the students, this had implications for the students, namely not finishing their degree during the regular period, but only later in sepember, potentially negativelly implacting on their first job seeking). In this sense, and even though a specific institutional decision is always a commitment of several parties regarding internships, it seems that the decisions taken do not always equally benefits for those involved in the process.

\subsection{Case D: "Internhips Are Valuable Resources, Not Just for Students"}

Within this focus group, internal problems where mentioned seven times and external problems were also mentioned seven times (cf. Table 6). Contrarily to Cases A and B, and similarly to what happened in Focus Group C, a more balanced scenario between internal and external problems emerged. 
Table 5. The 'lunar side' of internships from Case C—categories, subcategories, and illustrative examples.

\begin{tabular}{|c|c|c|}
\hline Category & Relation to the Institution & (Subcategories) and Examples of Testimony \\
\hline Curricular design (3 references) & Internal & $\begin{array}{l}\text { "This year we had a student who started his internship with no extracurricular unit } \\
\text { besides the regular one [some students leave one or two curricular units to be finished at } \\
\text { the end of the degree]. And he said to me he wanted to quit, because he was not able to } \\
\text { attend classes and the internship at the same time" (Degree Director). }\end{array}$ \\
\hline Lack of (adequate) institutional support (2 references) & Internal & $\begin{array}{l}\text { "We do not have enough human resources to implement several internships along a } \\
\text { study program. This would imply a higher support. (... ) Nowadays what is demanded } \\
\text { from polytechnic institutions is much different from the past" (Head of Department). }\end{array}$ \\
\hline $\begin{array}{c}\text { University Teachers (Assure teaching hours) (2 } \\
\text { references) }\end{array}$ & Internal & $\begin{array}{l}\text { "It is important to remember here the Bologna Reform. Before this reform our degrees } \\
\text { were longer ( } 4-5 \text { years). Then, we had to remove some curricular units. ( ... ) So, we took } \\
\text { internships out" (Degree Director) }\end{array}$ \\
\hline $\begin{array}{l}\text { Different modus operandi of companies in comparison } \\
\text { to the academia ( } 8 \text { references) }\end{array}$ & External & $\begin{array}{l}\text {... concerning students' evaluation "I cannot specify all the details, but the student had } \\
\text { some kind of conflict with the external supervisor and we had to [correct the student's } \\
\text { classification] because she had done an excellent job" (Degree Director, Tourism) } \\
\ldots \text { concerning information management" One student presented, in her report, the } \\
\text { annual billed money from marriages (... ) and the employer [demanded that this } \\
\text { information would be taken out from the report] ... it was confidential information." } \\
\text { (Degree Director, Management) } \\
\ldots \text { concerning students' selection "The [name of company] demands students to undergo } \\
\text { a psychometric test. And sometimes they are rejected." (Head of Department) } \\
\ldots \text { on working agendas/schedules "Students used to go to the company during the } \\
\text { afternoon. During the morning they attended classes at the university. But some } \\
\text { companies stated that they would prefer to have students all day." (Degree Director, } \\
\text { Management) }\end{array}$ \\
\hline
\end{tabular}


Table 6. The 'lunar side' of internships from Case D—categories, subcategories, and illustrative examples.

\begin{tabular}{|c|c|c|}
\hline Category & Relation to the Institution & Example of Testimony \\
\hline Lack of institutional support ( 6 references) & Internal & $\begin{array}{l}\text {... On what concerns to an evaluation strategy } \\
\text { "Clearly, the internship commissions could do a better job of systematization, like it used } \\
\text { to be done in the past." (Degree Director) }\end{array}$ \\
\hline Curricular design (1 reference) & Internal & $\begin{array}{l}\text { "students' sometimes refer, in their reports, that the internships are too short. They state } \\
\text { that they would prefer longer internships, but this would have implications on the study } \\
\text { program." (Head of Department) }\end{array}$ \\
\hline Lack of adequate internship placements (4 references) & External & $\begin{array}{l}\text { "[interns are also seen as] low-priced working force ... that is also true.... you cannot } \\
\text { dodge this issue (Degree Director) }\end{array}$ \\
\hline $\begin{array}{l}\text { Different modus operandi of companies in comparison } \\
\text { to the academia ( } 2 \text { references) }\end{array}$ & External & $\begin{array}{l}\text {... concerning evaluation ( } 1 \text { reference) } \\
\text { "We do not have a defined percentage for each evaluation component [classification from } \\
\text { the internal supervisor vs. external supervisor]. But we obviously balance the } \\
\text { classification according to the information we have ... even from other years. [A broader } \\
\text { picture that companies do not have]." } \\
\text {.. concerning the timing of 'high workload' } \\
\text { "So, there is a different cycle of work (...) students ended up falling into offices during a } \\
\text { peak period of corporate work, when the availability to accompany the internship is also } \\
\text { lower. And we [university] too (...) there are times when we are more available to } \\
\text { provide guidance (...)". (Degree Director) }\end{array}$ \\
\hline Students' profile (1 reference) & External & $\begin{array}{l}\text { "Students maturity has been dropping over the last years. Nowadays students are much } \\
\text { less mature at the end of a degree than ... ten years ago. So, if back then we already opted } \\
\text { for a final internship, now this decision makes even more sense [students undergoing an } \\
\text { internship at the end when they are more work-ready]." (Head of Department) }\end{array}$ \\
\hline
\end{tabular}


The most negative internal aspect mentioned was the lack of an adequate evaluation strategy from the Internship Commission. In this institution, as opposed to the previous cases, an established internal service supports the management of internships. However, and according to a supervisor's testimony, the present work model does not consider the monitoring of graduates:

"Back then [before the Bologna reform] ... the evaluation of internships was done with another approach (... ). In the past, in class, meetings focused on internship evaluation. We identified the students who managed to get a job as a consequence of their internship (... ) Nowadays, with this new model this does not happen. When the jury gets togeteher during the Viva of the internship, we talk about this and get an idea, but it is an informal information, nothing is registered. Currently, the Internship Comission does not do this. Perhaps it would be a good practice to readopt it."

The second internal negative aspect, with one reference, was mentioned by the Head of Department and was related to curricular design. Accordingly, some students tend to complain that internships tend to be too short, indicating, as in previous institutional cases, fragilities regarding curricular design.

Concerning external negative aspects, the challenge of assuring adequate internship placements was mentioned four times ( 1 time by Degree Director, 3 times by the Degree Director with previous supervisor experience). In order to ensure an internship placement to every student-since internships are compulsory-the institution opens the possibility of students to attend internships at their home town, which also allows students to avoid additional expenses. By adopting this strategy this institution has the 'opposite' problems of Institution C (too many candidates for a shortage of internship placements):

"Sometimes we have the opposite situations (... ), this is, some companies ask us for students ... and we do not have enough students to 'offer'. This is our problem, never the other way around. We never had a situation were a student did not get an internship placement. We have a lot of company requests, asking us for interns and we don't have the ability to provide these interns because we give students the freedom to attend their internship where they want (...) so, we don't respond so promptly to what local businesses request (... )."

(Head of the Department)

As in Case $\mathrm{C}$, the difficulties associated with different work structures between the academia and the institutions were also mentioned ( 2 references). While a first difficulty is related to assessment strategies, the other refers to the fact that the working calendars of the academia and the business world do not always match.

Problems associated with the changing students' profiles were mentioned by the Head of Department. As reported, students are becoming more immature, and therefore tend to be less prepared to attend an internship and experience real working contexts. This was one of the main arguments used to avoid integrating several internships along the study program $[13,14]$. In his opinion, immature students might cause more harm than good to companies, which cannot only backlash against further partnerships with the university but could also lose its value as a resource for the student:

"It would turn out to be a burden for companies (...) students would be exclusively there for learning and would not not result in contributions to the company, so this would be a win relationship for only one of the parties. For the other part, it would present no return on investment".

(Head of Department)

Furthermore, the integration of several internships along the study program would imply more expenses for students. All agreed that the present strategy, one final compulsory internship, was the best strategy for their specific context: “( ... ) This is why it makes sense that the internship is (just) at the end of the degree." (Student). Finally, acknowledging the importance of internships for students (as learning experiences), but also for institutions (as a labour force source) and universities (as an 
instrument for partnerships with local businesses), the Head of Department shared that his institution once prepared a project looking for financial support in order to pay a grant to students and also to supervisors involved in internships. This would allow in valuing the entire internship exercise, but he only got it for one school year, as the Head of the Department regretted.

\section{Discussion: Framing the 'Lunar Side' of Curricular Internships-Implications for Sustainable Institutional Management}

In order to understand the process of planning and offering curricular internships, four focus groups, involving 21 participants from four public Portuguese HEIs, were conducted. The value of curricular internships was globally recognized and is described in [4]. Within this particular article, the negative aspects ('lunar sides'), an often neglected facet of internship management, are elicited and explored. Globally, 38 references to internal challenges and 40 references to external challenges were made by the participants of the four HEIs (Table 7), indicating a balanced scenario between internal (fragilities) and external (threats) problems.

Table 7. The 'lunar side' of curricular internships—a global scenario of the four cases.

\begin{tabular}{|c|c|c|c|c|c|c|}
\hline \multicolumn{2}{|l|}{ Negative Features } & \multirow{2}{*}{$\begin{array}{l}\text { Case A } \\
\text { (Coast) }\end{array}$} & \multirow{2}{*}{$\begin{array}{l}\text { Case B } \\
\text { (Inland) }\end{array}$} & \multirow{2}{*}{$\begin{array}{l}\text { Case C } \\
\text { (Inland) }\end{array}$} & \multirow{2}{*}{$\begin{array}{c}\text { Case D } \\
\text { (Coastland) }\end{array}$} & \multirow{2}{*}{ Total } \\
\hline Category & $\begin{array}{l}\text { Relation to } \\
\text { HEIs }\end{array}$ & & & & & \\
\hline Lack on institutional support & & 5 & 9 & 2 & 7 & 23 \\
\hline Curricular Design & Internal (38) & 4 & 4 & 3 & 1 & 12 \\
\hline Teachers & & 1 & 0 & 2 & 0 & 3 \\
\hline Lack of adequate internship & & 5 & 16 & 0 & 4 & 25 \\
\hline placements Different modus operandi & & & & & & \\
\hline of Academia and Companies & External (40) & 0 & 0 & 8 & 2 & 10 \\
\hline Manipulation of internship allocation & & 0 & 4 & 0 & 0 & 4 \\
\hline Students & & 0 & 0 & 0 & 1 & 1 \\
\hline Total & & 15 & 33 & 15 & 15 & 78 \\
\hline
\end{tabular}

The most referred to problem is of an external nature, namely the lack of adequate curricular internships ( 25 references). This problem was mentioned within all four cases but was particularly relevant in CASE B, an institution located in the interior of the country, where the number of companies is much lower than in the coastal zones and large urban areas $[43,44]$. In the other three institutions, however, it was also reported that not every company is acceptable to receive interns. It is not just a matter of guaranteeing an internship placement. The quality of the learning experience has also to be actively monitored and annually evaluated (even though this has been largely done in an informal way) in order to avoid situations of interns being used as 'cheap work force', a tendency that is regarded as a growing problem, as it is mentioned by [49-51]. Hence, it constitutes a significant barrier in terms of the achievement of target 8.6 from the SDA. Furthermore, due to unemployment problems, fostered by the economic crisis, and to the 'positive reputation' of internships, this strategy has been widely disputed by HEIs, and mechanisms to try to 'manipulate' the system were alluded to, requiring an even closer monitoring strategy. This situation rises concerns regarding equal access of students to internship opportunities and strategies to ensure this. Recent research has been claiming that internships are replicating social inequalities [51,52]. As such, institutional investments in monitoring and evaluating these strategies are crucial to grant equal access of students to internships and guarantee the quality of the learning experiences, as envisaged by the Agenda 2030 (Goal 4). Surprisingly, despite its almost ubiquitous nature, internships evidence is still scant and isolated, as stated by a recent literature review [25]. On a similar note Hunt and Scott [50] state: “( ... ) it is surprising how unsystematic much evidence about internships remains. Little quantitative evidence exists on the extent of the practice, the proportion of unpaid internships, or the nature and relative quality of paid and unpaid internships (... )." [p.1]. Of course, these investments require adequate human resources at universities, leading to the second most frequent identified problem. In fact, an internal issue, common to all four cases, was the lack of institutionalized support (with 23 mentions). This support could be given, inter alia, 
by internship offices or commissions. In fact, the public movement of HEIs in adopting curricular internships $[25,33]$ and the investment in communicating this type of strategy to the general public contrast with the lack of supportive structures and administrative staff training. One HEI (CASE A) stood out by mentioning that even the existent support leaves much room for improvements. Therefore, one recommendation that would benefit the institutions as a whole, and especially the Departments involved in curricular internships, would be to invest in supportive structures and in the training of the involved staff. As highlighted by one participant in the focus groups, this training could involve, for example, the identification of adequate institutions to receive internships and the establishment of the initial contacts. Supportive training strategies for academics should also be considered. In fact, a recent study indicates that the relationship between supervisor and students strongly influences the quality of the learning experiences during the internship and the positive outputs after graduation [18]. The goal of strengthening capacity in technical and vocational skills, as envisaged by SDA 2030, cannot be reduced to the simple offer of internships. A more sustained holistic support is needed at several levels and this entails investments in capacitating university teachers in dealing with the business world, namely regarding issues such as students' evaluation, report writing and sensibilization regarding decent work conditions and social responsibility, as envisaged by the SDA. Another aspect that emerged from the cases was the lack of a mechanism to share and spread the strategies used to overcome specific problems, that is, to do benchmarking. While there is a global recognition of the value of internships, and active efforts are made to maximize their benefits to students, HEIs, and even companies, do not share good practices with others. This is another indicator of the present unsustainability of internship management. According to Guerra and Costa [53] an indicator of sustainability is when 'new and successful strategies become a normalized practice within the working teams or institutions' (p. 12).

Finally, these case studies evidenced that the relationships among identified factors are context dependent (being context defined in space and time) and, indeed, complex. In fact, each factor does not exist per se but is strongly interrelated with others. This is the reason why moments of participatory reflection are crucial to managing curricular internships in a sustainable manner, thus articulating the 'lunar' and 'solar' sides of internships, which are, in fact, inseparable'. Indeed, in two specific cases, namely A and B, primers towards innovation and change emerged. The Director of CASE A reported that he would reanalyze the study programs in order to enhance working contacts with internships. The Dean of CASE B recognized the lack of monitoring and evaluating structure at his institution and acknowledged its positive future consequences. It is believed that these moments of participatory reflection should be done on a regular basis, since roles and persons change over time (a supervisor is not only a supervisor in the university, and a student is not only an intern during his/her internships, as he/she will be a future employee and perhaps a future employer) [50]. Internship management needs to be thought of in a long term perspective in order to maximize its sustainability and impact [52].

\section{Concluding Remarks}

The majority of scientific research has been advocating internships' positive outputs regarding the personal development of graduates (employability) and their work integration (employment). So why are those not a universal reality among HEIs? Why are internships not a 'miraculous' solution? A conceptual refocus on the discussion of curricular internship management was proposed within this paper by eliciting the 'lunar side' of this particular pedagogical strategy.

Beyond this theoretical concern, this study also embraced a holistic and therefore innovative approach by exploring a pluralist perspective on the implications and outputs of curricular internships in HE, using the Portuguese context as an illustrative scenario. National specificities such as the HE subsystem (polytechnic schools vs. universities) and HEI location (inland vs. coastland) have been considered. The same happened with the nature of internship experiences (facultative vs. compulsory). The adopted qualitative methodological approach allowed the sharing and confrontation of different perceptions on the value of curricular internships 'in loco' and 'in first hand'. 
Indeed, the methodological option of organizing heterogeneous focus groups proved to be very valuable to collect evidence on the 'lunar side' of internships, by allowing the confrontation of different perceptions. Thus, in order to consider both the 'solar' and 'lunar' sides of internships, which is essential to address the sustainability of internship policies, future qualitative studies should consider the combination of different evidence collection methods, such as individual interviews and heterogeneous focus groups.

Data analysis showed no major differences in terms of subsystems (university vs. polytechnic). Instead, findings showed more differences regarding the geographical location of HEIs and the nature of the internships offered. Thus, regarding internships, it seems that the once sharp distinction between HE subsystems is effectively becoming blurred over time.

The research conducted also identified three latent tensions: (i) the tension between the perceived need to extend the duration of the curricular internships and the difficulty to accommodate that extension in the total workload of the programs without compromising its other components, (ii) the tension between supervisors (and program directors) and the management of the institutions relating the lack of institutional support to organize and manage curricular internships, and (iii) the tension between HEIs and hosting companies concerning the unbalance between the demand and supply of proper internship placements.

Although the concrete contexts may shape the identified tensions (the direction of the imbalance between the supply and the demand for internship placements may vary between regions or areas of studies, for example), they are rather general and would probably be observed in other institutions. Thus, the main general implication of the study is that institutions must carefully consider and manage the three identified tensions in order to develop and implement sustainable internship strategies. Some initiatives towards complying with that need were identified by the study and can be used as examples: (i) to find innovative ways of accommodating long internships into the program workload (for example by anticipating contact with future hosting companies within the scope of other curricular units, by diminishing the workload of competing curricular units, and by adjusting schedules), (ii) to revisit the attributions of the internship commissions (or create them if they do not exist) assuring effective administrative support for internship management, including for the allocation of students to internship placements, (iii) to train all the personnel involved in internships, including academics and administrative staff, and (iv) to carefully monitor the concrete internship experiences, in order to be able to select the best hosting institutions, and, whenever needed, to adopt innovative strategies to extend the internship offer (for example by advertising that need or by establishing an advisory committee with local businessmen).

Finally, regarding the social, economic and institutional dimensions of sustainable development, successful institutional strategies of curricular internship management can only emerge through a holistic approach, which integrates both the positive and the negative aspects of internships (the 'solar' and the 'lunar' sides), and balances the interests of all the stakeholders involved. Sustainable institutional strategies should thus envisage curricular internships both as an asset and as a liability.

Although the findings of the present study are useful to the definition of institutional politics regarding the design and implementation of internships in FCD, the following limitations should be highlighted. First, the number of participants in the focus groups was something that the research team could not control and therefore the comparison of settings was more difficult. Second, evidence was obtained through the second round of content analysis (the first one occurred in 2014 and the second one in 2019). This new look at the data evidenced students were less willing to share their opinion regarding the negative aspects of internships. It is not clear if this could be due to their more 'fragile' position within the focus group, when compared to supervisors or degree directors, which could lead them to feel more intimidated to share their real vision on internships, or whether they have generally a more positive outlook. This should be clarified. Moreover, while a mixed focus group was important, this methodological strategy could also be strengthened by combining it with individual interviews. Along with this pitfall, future research needs to take employees' perspectives into account. While 
focus group participants reported difficulties in bridging both worlds, the perspectives of hosting institutions might further elicit both the difficulties and the strategies to enhance partnerships for more sustainable internships. Third, as a within-case study, the main goal of this research was not the generalization of its results. Rather, this research sought to provide suggestions on how internships can be better planned, implemented and assessed. Future research will extend the study to further institutions. Furthermore, external supervisors will also be invited to participate in the focus groups. The idea is to crosscheck their perceptions regarding internships with the perceptions of interns and internal institutional stakeholders.

Author Contributions: Conceptualization (larger project): G.P.D., A.I.M. \& P.S.; Methodology (larger project): B.L., P.S., A.I.M., E.B., G.P.D. \& M.C. Analysis (qualitative component): B.L. \& P.S.; Validation (of qualitative analysis): A.I.M. \& E.B.; writing-Original draft preparation: B.L.; writing-Review and editing: B.L., G.P.D., A.I.M., P.S. \& E.B.

Funding: Research was funded by POAT_Programa Operacional de Assistência Técnica within the scope of "Quadro de Referência Estratégica Nacional-QREN". Project number 000779402013. The funders had no role in the design of the study; in the collection, analyses, or interpretation of data; in the writing of the manuscript, or in the decision to publish the results.

Acknowledgments: The authors acknowledge all informants involved in the study, as well as the administrative and technical support of the hosting institutions of the researchers.

Conflicts of Interest: The authors declare no conflict of interest.

\section{References}

1. United Nations General Assembly. Transforming Our World: The 2030 Agenda for Sustainable Development; Resolution 70/1; Document A/RES/70/1; United Nations General Assembly: New York, NY, USA, 2015.

2. Spangenberg, J.H. Scenarios and indicators for sustainable development: Towards a critical assessment of achievements and challenges. Sustainability 2019, 11,942. [CrossRef]

3. Spangenberg, J.H. Institutional sustainability indicators: An analysis of the institutions in Agenda 21 and a draft set of indicators for monitoring their effectivity. Sustain. Dev. 2002, 19, 103-115. [CrossRef]

4. Paiva Dias, G.; Melo, A.I.; Lopes, B.; Seabra, D.; Brito, E.; Costa, M.; Silva, P. Os Estágios Curriculares e o Seu Impacto na Empregabilidade dos Licenciados [Curricular Internships and Its Impact on Graduates Employability]; UA Editora: Aveiro, Portugal, 2015; ISBN 978-972-789-443-7.

5. Teichler, U. Bologna-Motor or Stumbling Block for the Mobility and Employability of Graduates? In Ulrich Teichler and Harald Schomburg "Employability and Mobility of Bachelor Graduates in Europe Key Results of the Bologna Process"; Sense Publishers: Boston, MA, USA, 2011; Available online: http://www.forschungsnetzwerk. at/downloadpub/361-employability-and-mobility-of-bachelor-graduates-in-europe.pdf (accessed on 10 July 2019).

6. European Commission. Modernization of Higher Education in Europe: Access, Retention and Employability; Office of the European Union: Luxembourg, Luxembourg, 2014.

7. European Commission. Education and Training Monitor Report-Volume 2, Portugal; Office of the European Union: Luxembourg, Luxembourg, 2016; Available online: http://ec.europa.eu/education/policy/strategicframework/et-monitor_en\#country (accessed on 27 August 2019).

8. Kessels, J.; Kwakman, K. Interface: Establishing Knowledge Networks Between Higher Vocational Education and Businesses. High. Educ. 2007, 54, 689-703. [CrossRef]

9. Guile, D.J. Learning to work in the creative and cultural sector: New spaces, pedagogies and expertise. J. Educ. Policy 2010, 25, 465-484. [CrossRef]

10. Clark, M.; Zukas, M. Understanding successful sandwich placements: A Bourdieusian approach. Stud. High. Educ. 2016, 41, 1281-1295. [CrossRef]

11. Stiwne, E.; Gaio-Alves, M. Higher Education and Employability of Graduates: Will Bologna make a difference? Eur. Educ. Res. J. 2010, 9, 32-44. [CrossRef]

12. Daniels, J.; Brooker, J. Student identity development in higher education: Implications for graduate attributes and work-readiness. Educ. Res. 2014, 56, 65-76. [CrossRef]

13. Hurst, J.L.; Good, L.K. A 20-year evolution of internships: Implications for retail interns, employers and educators. Int. Rev. Retail Distrib. Consum. Res. 2010, 20, 175-186. [CrossRef] 
14. Tynäla, P. Toward a 3 -P Model of workplace learning: A literature review. Vocat. Learn. 2013, 6, 11-36. [CrossRef]

15. Silva, P.; Lopes, B.; Costa, M.; Seabra, D.; Melo, A.I.; Brito, E.; Dias, G.P. Stairway to employment? Internships High. Educ. High. Educ. 2016, 72, 703-721.

16. Silva, P.; Lopes, B.; Costa, M.; Melo, A.I.; Dias, G.P.; Brito, E.; Seabra, D. The million-dollar question: Can internships boost employment? Stud. High. Educ. 2018, 43, 2-21. [CrossRef]

17. Sin, C.; Tavares, O.; Amaral, A. Student perceptions of the employability of the first degree in Portugal. Educ. + Train. 2016, 58, 966-983. [CrossRef]

18. Franco, M.; Silva, R.; Rodrigues, M. Partnerships between Higher Education Institutions and firms: The role of students' curricular internship. Ind. High. Educ. 2019, 33, 172-185. [CrossRef]

19. Morgenstern, L.F. Las prácticas académicas externas: Reflexiones para los estudios de Sociología. Rev. Esp. Sociol. 2016, 25, 137-151.

20. Xia, J.; Caulfield, C.; Ferns, S. Work-integrated learning: Linking research and teaching for a win-win situation. Stud. High. Educ. 2015, 40, 1560-1572. [CrossRef]

21. Jackson, D.; Wilton, N. Developing career management competencies among undergraduates and the role of work-integrated learning. Teach. High. Educ. 2016, 21, 266-286. [CrossRef]

22. Smith, C.; Worsfold, K. Unpacking the learning-work nexus: 'priming' as lever for high-quality learning outcomes in work-integrated learning curricula. Stud. High. Educ. 2015, 40, 22-42. [CrossRef]

23. Teichler, T. Higher Education and the World of Work: Conceptual Frameworks, Comparative Perspectives and Empirical Findings; Sense Publishers: Rotterdam, The Netherlands, 2009.

24. Wilton, N. The impact of work placements on skill development and career outcomes for business and management graduates. Stud. High. Educ. 2012, 37, 603-620. [CrossRef]

25. Mirrales- Quirós, M.; Jerez-Barroso, L. The interrelationship between internship and employability: A critical literature review. Proceedings 2018, 2018, 1328. [CrossRef]

26. Frankam, J. Employability and higher education: The follies of the 'Productivity Challenge' in the Teaching Excellence Framework. J. Educ. Policy 2017, 32, 628-641. [CrossRef]

27. Trede, F.; McEwen, C. Early workplace learning experiences: What are the pedagogical possibilities beyond retention and employability? High. Educ. 2015, 69, 19-32. [CrossRef]

28. Yorke, M.; Knight, P. Embedding Employability into the Curriculum; The Higher Education Academy: York, UK, 2006.

29. Alves, M.G. Graduate's Learning Across Educational and Professional Settings: Outlining an Approach. In Graduate Employability in Context: Theory, Research and Debate; Tomlinson, M., Holmes, L., Eds.; Palmgrave McMillian: London, UK, 2017; pp. 171-194.

30. Weible, R. Are universities reaping the available benefits internship programs offer? J. Educ. Bus. 2009, 85, 59-63. [CrossRef]

31. Giret, J.F.; Issehnane, S. L'effet de la qualité des stages sur l'insertion professionnelle des diplômés de l'enseignement supérieur. Form. Empl. 2012, 1, $29-47$.

32. Govender, C.M.; Taylor, S. A work integrated learning partnership model for Higher education graduates to gain employment. S. Afr. Rev. Sociol. 2015, 46, 43-59. [CrossRef]

33. Spence, C. 'Judgement' versus 'metrics' in higher education management. High. Educ. 2019, 77, 761-775. [CrossRef]

34. Barr, T.F.; McNeilly, K. The Value of Students' Classroom Experiences from the Eyes of the Recruiter: Information, Implications, and Recommendations for Marketing Educators. J. Mark. Educ. 2002, 24, 168-173. [CrossRef]

35. Tomlinson, M. 'The degree is not enough': Students' perceptions of the role of higher education credentials for graduate work and employability. Br. J. Sociol. Educ. 2008, 29, 49-61. [CrossRef]

36. Divine, R.; Miller, R.; Wilson, J.H.; Linrud, J. Key philosophical decisions to consider when designing an internship program. J. Manag. Mark. Res. 2008, 2, 1-8.

37. Matthew, S.; Taylor, R.; Ellis, R. Relationships between students' experiences of learning in an undergraduate internship programme and new graduates' experiences of professional practice. High. Educ. 2012, 64, 529-542. [CrossRef]

38. Gault, J.; Leach, E.; Duey, M. Effects of business internships on job marketability: The employers' perspective. Educ. Train. 2010, 52, 76-88. [CrossRef] 
39. Weiss, F.; Klein, M.; Grauenhorst, T. The effects of work experience during higher education on labour market entry: Learning by doing or an entry ticket? Work Employ. Soc. 2014, 28, 788-807. [CrossRef]

40. Humburg, M.; van der Velden, R. Skills and the graduate recruitment process: Evidence from two discrete choice experiments. Econ. Educ. Rev. 2015, 49, 24-41. [CrossRef]

41. Barbusse, B.; Glaymann, D.; Grima, F. Les stages étudiants peuvent-ils contribuer à sécuriser les parcours professionnels dans la phase d'insertion. Relief-Céreq 2007, 22, 231-233.

42. Creswell, J.W. Research Design: Qualitative, Quantitative and Mixed Method Approaches; Sage: Sauzend Oakes, CA, USA, 2014.

43. National Institute for Statistics-INE. Territorial Portrait of Portugal, 2017. Available online: file://C: /Users/blopes/Downloads/09RTP2017_EN.pdf (accessed on 27 August 2019).

44. Nário, M.; Melo, A.I.; Biscaia, R.; Rocha, P.; Santos, C.; Ferreira, A.; Dias, D.; Gomes, G.; Azevedo, G.; Duarte, R.; et al. O Impacto do Turismo das Aldeias Históricas de Portugal: Um Quadro de Análise [The Impact of Tourism on the Historical Villages of Portugal: A Framework for Analysis]. Finisterra 2019, 54, 21-36.

45. Silva Lopes, B.; Pedrosa-de-Jesus, H.; Watts, M. The Old Questions Are the Best: Striving against Invalidity in Qualitative Research. In Theory and Method in Higher Education Research; Huisman, J., Tight, M., Eds.; Emerald Group Publishing: Bingley, UK, 2016; pp. 1-22.

46. Gray, D.E. Doing Research in the REAL World; Sage: London, UK, 2004.

47. Koichu, B.; Harel, G. Triadic Interaction in clinical task-based interviews with mathematics teachers. Educ. Stud. Math. 2007, 66, 349-371. [CrossRef]

48. Allouche, J.; Schmidt, G. Os Instrumentos Fundamentais da Decisão Estratégica [Fundamental Instruments towrds Strategic Decision]; Vislis Editores: Lisboa, Portugal, 1999.

49. Hunt, W.; Scott, P. Paid and unpaid graduate internship: Prevalence, quality and motivations fix month after. Stud. High. Educ. 2019. [CrossRef]

50. Rose, P. The intern to employee career transition: An outsider perception of insider status. J. Career Dev. 2018, 45, 566-579. [CrossRef]

51. Grant-Smith, D.; Mc Donald, P. Ubiquitous yet ambiguous: An integrative review of unpaid work. Int. J. Manag. Rev. 2018, 20, 559-578. [CrossRef]

52. Smith, S.; Taylor-Smith, E.; Bacon, E.; Mackinnon, L. Equality of opportunity for work experience? Computing students of two UK universities "play the game". Br. J. Sociol. Educ. 2019, 40, 324-339. [CrossRef]

53. Guerra, C.; Costa, N. Sustentabilidade da investigação Educacional: Contributos da literatura sobre o conceito, factores e acções. [Sustainability in Educational Research: Contributions from the literature to the concept, factors and actions]. Rev. Lusófona Educ. 2016, 34, 13-25. 